НАУЧНАЯ ХРОНИКА И БИБЛИОГРАФИЯ

CHRONICLES AND BIBLIOGRAPHY

\author{
УДК 94(47).084.2"1917" \\ МЕЖДУНАРОДНАЯ ЛЕТНЯЯ ШКОЛА \\ «1917 ГОД: НОВЫЕ ВЗГЛЯДЫ И НОВЫЕ ПОДХОДЫ» \\ ДЛЯ МОЛОДЫХ УЧЕНЫХ-ИСТОРИКОВ СТРАН СНГ, БАЛТИИ И ЕВРОПЫ
}

Для цитирования: Чикалова И. Р. Международная летняя школа «1917 год: новые взгляды и новые подходы» для молодых ученых-историков стран СНГ, Балтии и Европы // Запад - Восток. 2017. № 10. С. 252-253.

DOI: $10.30914 / 2227-6874-2017-10-252-253$

С 5 по 10 июня 1917 года в Санкт-Петербурге состоялась Международная летняя школа молодых ученых-историков стран СНГ, Балтии и Европы «1917 год: новые взгляды и новые подходы». В качестве ее главных организаторов выступили Институт всеобщей истории РАН, Санкт-Петербургский государственный университет и Международная ассоциация институтов истории стран СНГ. Проведение мероприятия стало возможным благодаря финансовой поддержке Межгосударственного фонда гуманитарного сотрудничества государств-участников СНГ и Российского научного фонда.

В работе школы приняли участие более 85 молодых ученых-историков и опытных преподавателей из Республики Армения, Республики Беларусь, Республики Казахстан, Кыргызской Республики, Латвийской Республики, Литовской Республики, Республики Молдова, Республики Таджикистан, Республики Узбекистан, Украины, Федеративной Республики Германия, Французской Республики, Чешской Республики и Японии. Российская Федерация в географическом отношении была представлена слушателями и преподавателями из Архангельска, Выборга, Екатеринбурга, Москвы, Новгорода, Петрозаводска и Санкт-Петербурга.

В центре внимания школы находились проблемы, связанные с национальными и региональными особенностями протекания революционных процессов в Российской империи. Большой блок вопросов касался новейших исторических источников, прежде всего архивных, и подходов к изучению истории Революции 1917 года. Так, в лекции профессора кафедры всеобщей истории РГПУ им. А. И. Герцена, доктора исторических наук Ю. З. Кантор детально, буквально день за днем, описывались события большевистского переворота 1917 года, идущие вразрез со сложившимися в общественном сознании историческими стереотипами. В лекции профессора кафедры всеобщей истории и методики преподавания истории Белорусского

(С) Чикалова И. Р., 2017 
государственного педагогического университета, доктора исторических наук И. Р. Чикаловой обсуждались гендерные аспекты революции. В выступлениях ведущего научного сотрудника Института всеобей истории РАН, доктора исторических наук В. В. Дамье и руководителя Сектора истории России, Украины и Белоруссии Института всеобщей истории РАН, доктора исторических наук А. В. Шубина были затронуты фундаментальные проблемы истории Великой российской революции и обозначены основные направления современной научной дискуссии. Благодаря лекциям профессора Филиппа Комта из Университета Сорбонны и профессора кафедры истории ШАГИ ИОН РАНХиГС, доктора исторических наук К. Н. Морозова слушатели получили возможность поразмышлять над причинами, ходом и последствиями Революции 1917 года в духе альтернативной истории.

Большинство лекций было посвящено национальной и региональной составляющей революции 1917 года в Российской империи. Слушатели познакомились со спецификой протекания революционных процессов в Армении, Бессарабии, Литве, Финляндии и в различных частях Центральной Азии. Выступавшими были озвучены современные научные оценки ключевых проблем истории революции и обозначены основные направления современной научной дискуссии в отношении ее событий. На занятиях также были затронуты проблемы формирования и сохранения исторической памяти о Великой российской революции.

Фоторепортаж, лекционные материалы и полная программа работы летней школы опубликованы на ее сайте: https://euruss.ru

И. Р. Чикалова

Поступила 20.10.2017; принята к публикащии 20.11.2017

*

Чикалова Ирина Ромуальдовна, доктор исторических наук, профессор, Белорусский государственный педагогический университет, г. Минск, Республика Беларусь, irinachikalova@gmail.com

\section{INTERNATIONAL SUMMER SCHOOL \\ "1917: NEW VIEWS AND NEW APPROACHES" FOR YOUNG SCIENTISTS IN CIS, BALTIC AND EUROPE}

Citation for an article: Chikalova I. R. International Summer school "1917: new views and new approaches" for young scientists in CIS, Baltic and Europe. West East. 2017, no. 10, pp. 252-253. DOI: 10.30914/2227-6874-2017-10-245-251

Submitted 20.10.2017; revised 20.11.2017

Irina R. Chikalova, Dr. Sci. (Philosophy), Full Professor, Minsk, The Republic of Belarus, irinachikalova@gmail.com 